\title{
PENERAPAN METODE MODIFIED DISTRIBUTION (MODI) UNTUK OPTIMALISASI BIAYA DISTRIBUSI PRODUK ALAT KESEHATAN
}

\author{
Reni Kurnia ${ }^{1}$, Windu Alfianti Shafira ${ }^{* 2}$, Rizka Oktaviani ${ }^{3}$, Muchammad Fauzi ${ }^{4}$ \\ 1,2,3,4Program Studi Teknik Industri, Universitas Widyatama Bandung \\ reni.kurnia@widyatama.ac.id ${ }^{1}$,windu.alfianti@widyatama.ac.id ${ }^{* 2}$, \\ oktaviani.rizka@widyatama.ac.id ${ }^{3}$, muchammad.fauzi@widyatama.ac.id ${ }^{4}$
}

\begin{abstract}
The transportation model is the lowest cost plan determination for a distribution process. This research aims to obtain the pattern of distribution of medical device products at PT X so that the costs for the distribution process become more optimal and the needs of product demand to each city can be met. By using Vogel's Approximation Method (VAM) as a viable initial solution and followed by optimization tests to determine the optimal solution with Modified Distribution Method (MODI). The results showed the initial solution of VAM method obtained cost Rp176,645,930 then Modified Distribution Method (MODI) as the optimal solution obtained optimal transportation costs of Rp176,645,210. Based on the results of calculations that have been done shows the results that the distribution of medical devices in $P T$. X by implementing a transport model can save on distribution costs.
\end{abstract}

Keywords: transportation problems, Vogel's Approximation Method (VAM), Modified Distribution Method (MODI).

\begin{abstract}
Abstrak
Model transportasi merupakan penentuan rencana biaya terendah untuk suatu proses distribusi. Penelitian ini bertujuan untuk mendapatkan pola pendistribusian produk alat Kesehatan pada PT X sehingga biaya untuk proses pendistribusian menjadi lebih optimal dan kebutuhan permintaan produk ke setiap kota dapat terpenuhi. Dengan menggunakan Vogel's Approximation Method (VAM) sebagai solusi awal yang layak dan dilanjutkan dengan uji optimalisasi untuk menentukan solusi optimal dengan Modified Distribution Method (MODI). Hasil penelitian menunjukan solusi awal metode VAM diperoleh biaya Rp176.645.930 kemudian Modified Distribution Method (MODI) sebagai solusi optimal diperoleh biaya transportasi optimal yaitu Rp176.645.210. Berdasarkan hasil perhitungan yang telah dilakukan menunjukkan hasil bahwa pendistribusian alat kesehatan di PT. X dengan menerapkan model transportasi dapat menghemat biaya distribusi.
\end{abstract}

Kata kunci: masalah transportasi, Vogel's Approximation Method (VAM), Modified Distribution Method (MODI). 
Jurnal Lebesgue : Jurnal Ilmiah Pendidikan Matematika, Matematika dan Statistika

Reni Kurnia, Windu Alfianti Shafira, Rizka Oktaviani, Muchammad Fauzi

Volume 2, No. 2, Agustus 2021 hal.166-179

DOI Artikel : 10.46306/lb.v2i2.66

\section{PENDAHULUAN}

Keberhasilan suatu industri manufaktur salah satunya yaitu komponen biaya, pemanfaatan biaya yang kreatif kreatif seminimal mungkin merupakan tujuan untuk mendapatkan keuntungan yang maksimal demi kelancaran suatu perusahaan dan proses pendistribusian merupakan salah satu kegiatan perusahaan yang erat kaitannya dengan meminimalkan suatu biaya. Mengirimkan barang ke tujuan dengan tepat waktu, dalam kondisi baik, dan dengan biaya yang efektif merupakan tiga hak pasokan. Sistem transportasi yang efisien adalah hal penting dalam memberikan layanan yang konsisten dan berkualitas kepada perusahaan. (Babu et al., 2016). Keefektifan jalur distribusi adalah hal yang penting bagi suatu perusahaan dalam upaya menekan pengeluaran biaya transportasi. (Muhamad et al., 2020). Masalah yang sering ditemukan dalam proses pendistribusian yaitu masalah transportasi. Dengan memperkecil biaya transportasi yang ada diperlukan keputusan yang tepat dalam pengalokasian produk jika pengalokasian suatu produk telah optimal maka akan tercapainya tujuan perusahaan yang ada yaitu mendapatkan keuntungan yang semaksimal mungkin dengan pengeluaran biaya yang seminimal mungkin. (Ardhyani, 2017).

PT X merupakan perusahaan yang bergerak dibidang alat Kesehatan, pendistribusian alat Kesehatan harus menjamin ketersediaan produk nya hingga kepelosok negeri dengan produk yang berkualitas dan pengiriman yang tepat waktu dengan biaya pengiriman yang seminimal mungkin. Kendala yang dialami oleh PT X yaitu pengalokasian produk yang ada belum mempunyai pola pendistribusian oleh karena itu biaya distribusi yang ada pada triwulan ketiga tahun 2020 yaitu sebesar Rp 186.360.697 menjadi tidak terkontrol jika dibandingkan dengan periode-periode sebelumnya yaitu pada triwulan pertama sebesar Rp 180.178.114 dan triwulan kedua sebesar Rp 181.754.759 sehingga pada triwulan ketiga tahun 2020 terjadi pembengkakan biaya distribusi, Hal ini dapat menyebabkan kerugian bagi perusahaan. Menghadapi situasi perusahaan tersebut maka diperlukan perbaikan untuk sistem transportasi sehingga penelitian ini dilakukan untuk mencari solusi dengan memilih jalur transportasi atau distribusi yang menentukan total biaya transportasi atau distribusi yang optimal. (Lestari \& Christy, 2018). Dalam hal permasalahan PT X ini model transportasi merupakan model yang cocok digunakan untuk mendapatkan pola pendistribusian produk alat kesehatan tersebut sehingga dapat menekan biaya untuk proses pendistribusian menjadi lebih optimal dan kebutuhan permintaan produk ke setiap kota dapat terpenuhi. Dengan menggunakan Vogel's Approximation Methode (VAM) sebagai solusi awal dan dilanjutkan dengan uji optimalisasi untuk menentukan solusi optimal dengan Modified Distribution Method (MODI). Modified Distribution Method (MODI) 
Jurnal Lebesgue : Jurnal Ilmiah Pendidikan Matematika, Matematika dan Statistika

Reni Kurnia, Windu Alfianti Shafira, Rizka Oktaviani, Muchammad Fauzi

Volume 2, No. 2, Agustus 2021 hal.166-179

DOI Artikel : 10.46306/lb.v2i2.66

dipilih karena metode ini merupakan pengembangan dari metode Stepping Stone, penentuan sel kosong yang dapat menghemat biaya dilakukan dengan prosedur yang lebih tepat dan dapat mencapai hasil yang optimal dengan lebih cepat, jumlah iterasi yang lebih sedikit dan perbaikan indeks yang dapat dicari tanpa harus menemukan loop dari setiap sel kosong, hanya dibutuhkan satu loop yang diperoleh setelah menentukan sel dengan indeks perbaikan terbesar. (Winda \& $\mathrm{Bb}, 2020)$.

\section{METODE PENELITIAN}

Jenis penelitian yang dilakukan merupakan penelitian terapan. Tujuan penelitian terapan adalah untuk mengaplikasikan, menguji, dan mengevaluasi kemampuan teori yang diterapkan untuk memecahkan masalah praktis (Sugiyono, 2013). Penelitian dilakukan di Perusahaan produk alat kesehatan yang berlokasi di Padalarang. Pengumpulan berupa data primer yaitu melakukan wawancara dengan bagian Purchasing dan PPIC (Production Planning and Inventory) di PT. X serta data sekunder yang diperoleh melalui buku, literatur, serta sumber lain yang terkait penelitian. Data yang diperoleh dari PT. X selanjutnya dilakukan analisis dan perhitungan terhadap data tersebut. Tahapan analisis data adalah sebagai berikut: (1) Memformulasikan masalah ke dalam program linear. (2) Perhitungan solusi awal dengan metode VAM. (3) Melakukan uji optimalitas dengan metode MODI.

\section{Program Linear Masalah Transportasi}

Diketahui notasi sebagai berikut:

m: sumber.

$\mathrm{s}_{\mathrm{i}},(\mathrm{i}=1,2,3, \ldots, \mathrm{m})$ : Pasokan (Supply).

$a_{i},(i=1,2,3, \ldots, m)$ : Kuantitas yang tersedia untuk setiap $m$ kapasitas.

n: tujuan.

$\mathrm{d}_{\mathrm{j}},(\mathrm{j}=1,2,3, \ldots, \mathrm{n})$ : Permintaan (Demand).

$b_{j},(j=1,2,3, \ldots, n)$ : Jumlah yang tersedia untuk setiap kebutuhan $n$.

$\mathrm{C}_{\mathrm{ij}}$ : Biaya pengiriman trans satu jumlah barang dari asal i sampai j di setiap jalur.

$\mathrm{X}_{\mathrm{ij}}$ : Jumlah kuantitas yang dikirim di setiap jalur dari asal i ke tujuan $\mathrm{j}$.

Ini kemudian dirumuskan secara matematis sebagai berikut.

minimize $Z=\sum_{i=1}^{m} \sum_{j=1}^{n} C i j X i j$

Batasan

$\sum_{j=1}^{n} X i j=a_{i}, i=1,2, \ldots, m$ 
Jurnal Lebesgue : Jurnal Ilmiah Pendidikan Matematika, Matematika dan Statistika

Reni Kurnia, Windu Alfianti Shafira, Rizka Oktaviani, Muchammad Fauzi

Volume 2, No. 2, Agustus 2021 hal.166-179

DOI Artikel : 10.46306/lb.v2i2.66

$\sum_{i=1}^{m} X i j=b_{j}, j=1,2, \ldots, n$

$x_{i j} \geq 0, i=1,2, \ldots, m, j=1,2, \ldots, n$

Dan

$\sum_{i=1}^{m} a_{i}=\sum_{j=1}^{n} b_{j}$

Menjadi kondisi seimbang yang keduanya diperlukan dan kondisi yang cukup untuk hasil yang layak (Hussein \& Shiker, 2020).

Vogel's Approximation Method (VAM)

Metode Vogel's Approximation (VAM) berkaitan dengan menemukan solusi optimal sambil mempertimbangkan hubungan indeks harga. Metode ini selalu membandingkan dua indeks harga terendah dalam satu kolom maupun dalam satu baris. Perbedaan ini digunakan untuk mengevaluasi di kotak mana kegagalan pengisian dengan varian termurah akan berdampak paling buruk pada hasil keseluruhan (Pečený et al., 2020).

VAM lebih baik dibandingkan dengan metode Least Cost dan North West Corner dalam mencari solusi awal yang layak. Langkah-langkah metode VAM yaitu (Nahar et al., 2018):

1. Untuk setiap baris dan kolom, tentukan ukuran penalti dengan mengurangi biaya unit terkecil pada baris dan kolom dari unit biaya terkecil.

2. Identifikasi baris atau kolom dengan penalti terbesar. Tentukan pilihan pada salah satu. Pada kolom atau baris yang terpilih, alokasikan sebanyak mungkin dengan biaya unit terkecil. Menyesuaikan pesediaan dan permintaan, serta menghapus baris atau kolom yang telah terpenuhi. Jika baris dan kolom memiliki nilai pinalti yang sama maka hanya satu yang dipilih, dan jika baris atau kolom tersisa adalah nol penawaran (permintaan).

3. (a) Jika sel yang tersisa untuk dipilih tepat satu baris atau kolom dengan nol persediaan atau permintaan, maka iterasi dihentikan.

(b) Jika masih tersisa satu baris atau kolom dengan persediaan atau permintaan positif, maka tentukan variable basis pada baris atau kolom dengan biaya terkecil dan hentikan iterasi.

(c) Jika yang belum terpilih pada semua baris dan kolom memiliki sisa persediaan dan permintaan, maka tentukan variabel basis dengan biaya terkecil dan hentikan iterasi.

(d) Jika tidak,ulangi langkah 1.

\section{Modified Distribution Method (MODI)}

Metode Modified Distribution (MODI) mengubah pengalokasian produk dengan menggunakan indeks yang diperhalus berdasarkan nilai tiap baris dan tiap kolom untuk mendapatkan pengalokasian yang optimal (Soplanit et al., 2019). Metode ini merupakan 
Jurnal Lebesgue : Jurnal Ilmiah Pendidikan Matematika, Matematika dan Statistika

Reni Kurnia, Windu Alfianti Shafira, Rizka Oktaviani, Muchammad Fauzi

Volume 2, No. 2, Agustus 2021 hal.166-179

DOI Artikel : $10.46306 / 1 b . v 2 i 2.66$

pengembangan dualitas dari metode stepping stone, MODI tidak menggunakan jalur tertutup untuk variable non basis, tetapi nilai Cij ditentukan secara bersama-sama dan jalur tertutup tetap digunakan untuk entering variable yang diidentifikasi (Mulyono, 2007). Langkah-langkah Modified Distribution Method dapat diringkas sebagai berikut:

1. Gunakan VAM sebagai penentuan solusi awal.

2. Mengitung nilai $u_{i}$ untuk tiap baris dan $v_{j}$ untuk tiap kolom menggunakan rumus $u_{i}+v_{j}=c_{i j}$ ke setiap variabel basis dengan asumsi awal $\mathrm{u}_{\mathrm{i}}=0$.

3. Menghitung $\mathrm{k}_{\mathrm{ij}}$, yaitu semua nilai perubahan biaya untuk setiap variabel non basis menggunakan rumus $\mathrm{c}_{\mathrm{ij}}-\mathrm{u}_{\mathrm{i}}-\mathrm{v}_{\mathrm{j}}=\mathrm{k}_{\mathrm{ij}}$

4. Pilih variable non basis yang memiliki nilai $\mathrm{k}_{\mathrm{ij}}$ paling negatif yang nantinya akan menghasilkan penurunan biaya terbesar. Kemudian dialokasikan sesuai dengan jalur stepping stone pada sel yang dipilih.

5. Ulangi langkah hingga nilai $\mathrm{k}_{\mathrm{ij}}$ nol atau tidak ada yang negatif.

\section{HASIL DAN PEMBAHASAN}

Optimasi distribusi dengan metode VAM-MODI, dimulai dengan pengumpulan data-data yang diperlukan yaitu data jumlah permintaan masing-masing lokasi distributor pada Tabel 1.

Tabel 1. Data Permintaan Produk Alat Kesehatan

\begin{tabular}{cccc}
\hline No & Kota & Kebutuhan & Satuan \\
\hline & Tangerang & & \\
1 & Selatan & 7252 & Box \\
\hline 2 & Jakarta Barat & 7634 & Box \\
\hline 3 & Yogyakarta & 6541 & Box
\end{tabular}

Data persediaan produk alat kesehatan di masing-masing gudang ditunjukkan pada Tabel 2.

Tabel 2. Data Persediaan Produk Alat Kesehatan di Gudang

\begin{tabular}{cccc}
\hline No & Gudang & Persediaan & Satuan \\
\hline 1 & Cimahi & 7893 & Box \\
\hline 2 & Bandung & 5223 & Box \\
\hline 3 & Padalarang & 7324 & Box
\end{tabular}

Data ongkos transportasi per satuan yang tercantum di Tabel 1 dan 2 yaitu box dari setiap gudang menuju masing-masing lokasi tujuan ditunjukkan pada tabel 3.

Tabel 3. Ongkos Transportasi Per Box dari Setiap Gudang ke Setiap Lokasi Distributor 


\begin{tabular}{cccc}
\hline Dari/Ke & $\begin{array}{c}\text { Tangerang Selatan } \\
(\mathbf{R p} / \mathbf{b o x})\end{array}$ & $\begin{array}{c}\text { Jakarta Barat } \\
(\mathbf{R p} / \mathbf{b o x})\end{array}$ & $\begin{array}{c}\text { Yogyakarta } \\
(\mathbf{R p} / \mathbf{b o x})\end{array}$ \\
\hline Cimahi & 7,220 & 7,060 & 12,670 \\
\hline Bandung & 7,340 & 7,190 & 12,800 \\
\hline Padalarang & 7,130 & 6,980 & 12,600
\end{tabular}

Berdasarkan seluruh data yang telah dikumpulkan kemudian diformulasikan ke dalam model matematis sebagai berikut.

minimum $Z=\sum_{i=1, j=1}^{m, n} C i j . X i j$

Minimum $Z=7220 X_{11}+7060 X_{12}+12670 X_{13}+7340 X_{21}+7190 X_{22}+12800 X_{23}+7130 X_{31}$ $+6980 \mathrm{X}_{32}+12600 \mathrm{X}_{33}$

Batasan Masalah

$$
\begin{aligned}
& X_{11}+X_{12}+X_{13}=7893 \\
& X_{21}+X_{22}+X_{23}=5223 \\
& X_{31}+X_{32}+X_{33}=7324 \\
& X_{11}+X_{21}+X_{31}=7252 \\
& X_{12}+X_{22}+X_{23}=7634 \\
& X_{13}+X_{23}+X_{33}=6541 \\
& X_{11}, X_{12}, X_{13}, X_{21}, X_{22}, X_{23}, X_{31}, X_{32}, X_{33} \geq 0
\end{aligned}
$$

\begin{tabular}{|c|c|c|c|c|}
\hline & $\begin{array}{c}\text { Tangerang } \\
\text { Selatan }\end{array}$ & Jakarta Barat & Yogyakarta & \multirow[t]{2}{*}{ Supply } \\
\hline & (D1) & (D2) & (D3) & \\
\hline Cimahi & 7220 & 7060 & 12670 & \multirow{2}{*}{7893} \\
\hline (S1) & & & & \\
\hline Bandung & \multirow[t]{2}{*}{7340} & 7190 & 12800 & \multirow{2}{*}{5223} \\
\hline \multicolumn{3}{|l|}{ (S2) } & & \\
\hline Padalarang & 7130 & 6980 & 12600 & \multirow{2}{*}{7324} \\
\hline (S3) & & & & \\
\hline
\end{tabular}

\section{Solusi Awal}

Solusi awal dicari dengan menggunakan metode VAM dengan penambahan kolom Dummy karena total kebutuhan lebih hesar dari total persediaan.

Tabel 4. Matriks Solusi Awal 
Jurnal Lebesgue : Jurnal Ilmiah Pendidikan Matematika, Matematika dan Statistika

Reni Kurnia, Windu Alfianti Shafira, Rizka Oktaviani, Muchammad Fauzi

Volume 2, No. 2, Agustus 2021 hal.166-179

DOI Artikel : $10.46306 / 1 b . v 2 i 2.66$

Demand $7252 \quad 7634 \quad 6541$

Pada setiap baris dan kolom, hitung ukuran pinalti dengan mengurangi biaya unit terkecil pada baris dan kolom dari unit biaya terkecil.

Tabel 5. Matriks Penyelesaian VAM 1

\begin{tabular}{|c|c|c|c|c|c|}
\hline & $\begin{array}{c}\text { Tangerang } \\
\text { Selatan }\end{array}$ & Jakarta Barat & Yogyakarta & \multirow[t]{2}{*}{ Supply } & \multirow[t]{2}{*}{ Penalti } \\
\hline & (D1) & (D2) & (D3) & & \\
\hline $\begin{array}{c}\text { Cimahi } \\
\text { (S1) }\end{array}$ & 7220 & 7060 & 12670 & 7893 & 160 \\
\hline $\begin{array}{c}\text { Bandung } \\
\text { (S2) }\end{array}$ & 7340 & 7190 & 12800 & 5223 & 150 \\
\hline $\begin{array}{c}\text { Padalarang } \\
\text { (S3) }\end{array}$ & 7130 & 6980 & 12600 & 7324 & 150 \\
\hline Dummy & 0 & 0 & 0 & 987 & 0 \\
\hline \multirow[t]{2}{*}{ Demand } & 7252 & 7634 & 6541 & 21427 & \\
\hline & 7130 & 6980 & 12600 & & \\
\hline
\end{tabular}

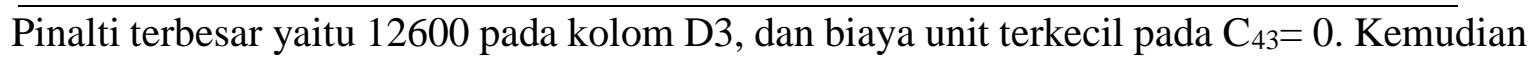
alokasikan sebanyak mungkin pada sel tersebut menyesuaikan persediaan dan permintaan yaitu 987. Hapus baris yang sudah terpenuhi.

Tabel 6. Matriks Penyelesaian VAM 2

\begin{tabular}{|c|c|c|c|c|c|}
\hline & $\begin{array}{c}\text { Tangerang } \\
\text { Selatan }\end{array}$ & Jakarta Barat & Yogyakarta & \multirow[t]{2}{*}{ Supply } & \multirow[t]{2}{*}{ Penalti } \\
\hline & (D1) & (D2) & (D3) & & \\
\hline $\begin{array}{c}\text { Cimahi } \\
\text { (S1) }\end{array}$ & 7220 & 7060 & 12670 & 7893 & 160 \\
\hline $\begin{array}{c}\text { Bandung } \\
\text { (S2) }\end{array}$ & 7340 & 7190 & 12800 & 5223 & 150 \\
\hline $\begin{array}{c}\text { Padalarang } \\
\text { (S3) }\end{array}$ & 7130 & 6980 & 12600 & 7324 & 150 \\
\hline Dummy & 0 & 0 & 0 & 0 & - \\
\hline
\end{tabular}


Jurnal Lebesgue : Jurnal Ilmiah Pendidikan Matematika, Matematika dan Statistika

Reni Kurnia, Windu Alfianti Shafira, Rizka Oktaviani, Muchammad Fauzi

Volume 2, No. 2, Agustus 2021 hal.166-179

DOI Artikel : 10.46306/lb.v2i2.66

987

\begin{tabular}{cccc} 
Demand & 7252 & 7634 & 5554 \\
\cline { 2 - 4 } Pinalti & 90 & 80 & 70
\end{tabular}

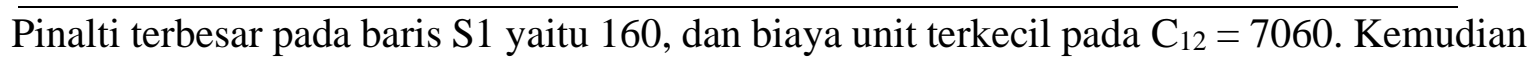
alokasikan barang sebanyak 7634. Hapus kolom yang sudah terpenuhi.

Tabel 7. Matriks Penyelesaian VAM 3

\begin{tabular}{|c|c|c|c|c|c|}
\hline & $\begin{array}{c}\text { Tangerang } \\
\text { Selatan }\end{array}$ & Jakarta Barat & Yogyakarta & Supply & Penalti \\
\hline & (D1) & (D2) & (D3) & & \\
\hline $\begin{array}{c}\text { Cimahi } \\
\text { (S1) }\end{array}$ & 7220 & 7060 & 12670 & 259 & 545 \\
\hline $\begin{array}{c}\text { Bandung } \\
\text { (S2) }\end{array}$ & 7340 & 7190 & 12800 & 5223 & 546 \\
\hline $\begin{array}{c}\text { Padalarang } \\
\text { (S3) }\end{array}$ & 7130 & 6980 & 12600 & 7324 & 547 \\
\hline Dummy & 0 & 0 & 0 & 0 & - \\
\hline Demand & 7252 & 0 & 5554 & & \\
\hline Pinalti & 90 & - & 70 & & \\
\hline
\end{tabular}

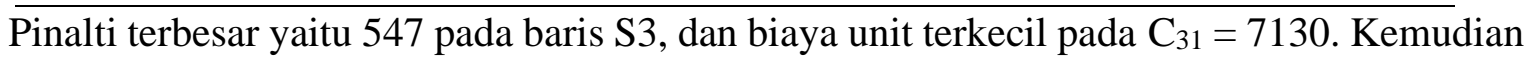
alokasikan barang sebanyak mungkin pada sel tersebut sebanyak 7634. Hapus kolom yang sudah terpenuhi.

Tabel 8. Matriks Penyelesaian VAM 4

\begin{tabular}{|c|c|c|c|c|c|}
\hline & $\begin{array}{c}\text { Tangerang } \\
\text { Selatan }\end{array}$ & Jakarta Barat & Yogyakarta & \multirow[t]{2}{*}{ Supply } & \multirow[t]{2}{*}{ Penalti } \\
\hline & (D1) & (D2) & (D3) & & \\
\hline $\begin{array}{c}\text { Cimahi } \\
\text { (S1) }\end{array}$ & 7220 & 7060 & 12670 & 259 & 12670 \\
\hline $\begin{array}{c}\text { Bandung } \\
\text { (S2) }\end{array}$ & 7340 & 7190 & 12800 & 5223 & 12800 \\
\hline $\begin{array}{c}\text { Padalarang } \\
\text { (S3) }\end{array}$ & 7130 & 6980 & 12600 & 72 & 12600 \\
\hline
\end{tabular}


Jurnal Lebesgue : Jurnal Ilmiah Pendidikan Matematika, Matematika dan Statistika

Reni Kurnia, Windu Alfianti Shafira, Rizka Oktaviani, Muchammad Fauzi

Volume 2, No. 2, Agustus 2021 hal.166-179

DOI Artikel : 10.46306/lb.v2i2.66

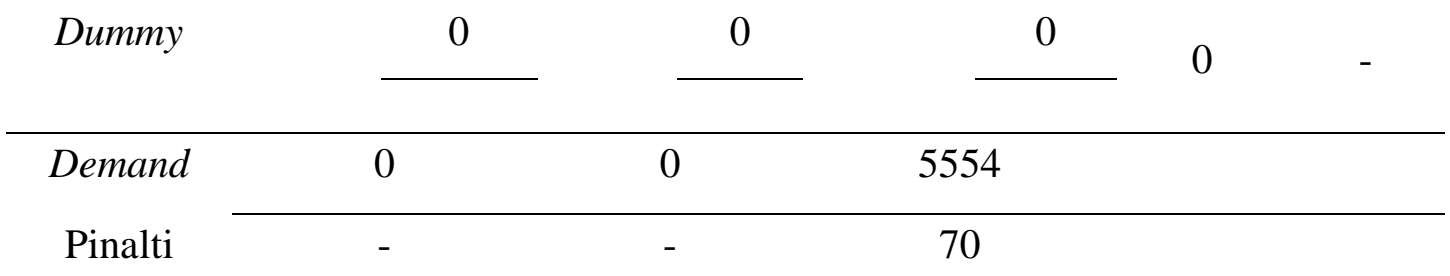

Pinalti terbesar pada baris S3 yaitu 12800, dengan biaya unit terkecil pada $\mathrm{C}_{23}=12800$. Kemudian alokasikan sebanyak mungkin pada sel tersebut menyesuaikan persediaan dan permintaan yaitu 5223. Hapus baris yang sudah terpenuhi.

Tabel 9. Matriks Penyelesaian VAM 5

\begin{tabular}{|c|c|c|c|c|c|}
\hline & $\begin{array}{c}\text { Tangerang } \\
\text { Selatan }\end{array}$ & Jakarta Barat & Yogyakarta & \multirow[t]{2}{*}{ Supply } & \multirow[t]{2}{*}{ Penalti } \\
\hline & (D1) & (D2) & (D3) & & \\
\hline $\begin{array}{c}\text { Cimahi } \\
\text { (S1) }\end{array}$ & 7220 & 7060 & 12670 & 259 & 12670 \\
\hline $\begin{array}{c}\text { Bandung } \\
\text { (S2) }\end{array}$ & 7340 & 7190 & 12800 & 0 & - \\
\hline $\begin{array}{c}\text { Padalarang } \\
\text { (S3) }\end{array}$ & 7130 & 6980 & 12600 & 72 & 12600 \\
\hline Dummy & 0 & 0 & 0 & 0 & - \\
\hline Demand & 0 & 0 & 331 & & \\
\hline Pinalti & - & - & 70 & & \\
\hline
\end{tabular}

Pinalti terbesar yaitu 12670 pada baris S1, dan biaya unit terkecil pada $C_{13}=12670$. Kemudian alokasikan sebanyak mungkin pada sel $\mathrm{C}_{13}$ menyesuaikan persediaan dan permintaan yaitu 259. Hapus baris yang sudah terpenuhi.

Tabel 10. Matriks Penyelesaian VAM 6

\begin{tabular}{|c|c|c|c|c|c|}
\hline & $\begin{array}{c}\text { Tangerang } \\
\text { Selatan }\end{array}$ & Jakarta Barat & Yogyakarta & Supply & Penalti \\
\hline & (D1) & (D2) & (D3) & & \\
\hline $\begin{array}{l}\text { Cimahi } \\
\text { (S1) }\end{array}$ & 7220 & 7060 & 12670 & 0 & - \\
\hline $\begin{array}{c}\text { Bandung } \\
\text { (S2) }\end{array}$ & 7340 & 7190 & 12800 & 0 & - \\
\hline
\end{tabular}


Jurnal Lebesgue : Jurnal Ilmiah Pendidikan Matematika, Matematika dan Statistika

Reni Kurnia, Windu Alfianti Shafira, Rizka Oktaviani, Muchammad Fauzi

Volume 2, No. 2, Agustus 2021 hal.166-179

DOI Artikel : $10.46306 / \mathrm{lb} . \mathrm{v} 2 \mathrm{i} 2.66$

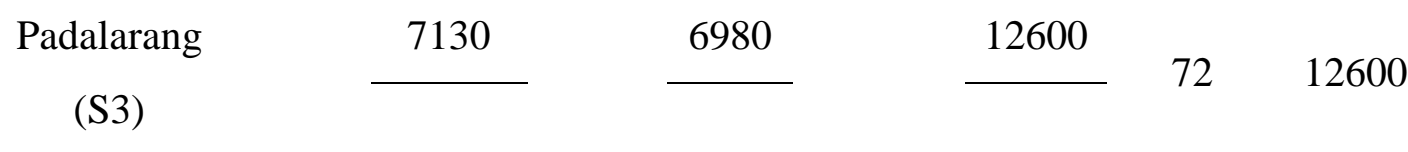

\begin{tabular}{|c|c|c|c|c|}
\hline Dummy & 0 & 0 & 0 & 0 \\
\hline Demand & 0 & 0 & 72 & \\
\hline Pinalti & - & - & 12600 & \\
\hline
\end{tabular}

Karena hanya tersedia tepat 1 kolom dan 1 baris yang sama maka alokasikan barang pada sel pertemuan yaitu $\mathrm{C}_{33}$ sejumlah 72 .

Tabel 11. Hasil Matriks Metode VAM

\begin{tabular}{|c|c|c|c|c|}
\hline & $\begin{array}{c}\text { Tangerang } \\
\text { Selatan }\end{array}$ & Jakarta Barat & Yogyakarta & \multirow[t]{2}{*}{ Supply } \\
\hline & (D1) & (D2) & (D3) & \\
\hline Cimahi & 7220 & \multirow[b]{2}{*}{7634} & \multirow[t]{2}{*}{12670} & \multirow{2}{*}{7893} \\
\hline (S1) & & & & \\
\hline Bandung & 7340 & 7190 & \multirow[b]{2}{*}{5223} & \multirow{2}{*}{5223} \\
\hline (S2) & & & & \\
\hline Padalarang & 7130 & 6980 & \multirow[t]{2}{*}{12600} & \multirow{2}{*}{7324} \\
\hline (S3) & 7252 & & & \\
\hline Dummy & 0 & 0 & 987 & 987 \\
\hline Demand & 7252 & 7634 & 6541 & 21427 \\
\hline
\end{tabular}

Dari tabel 11 dapat diperoleh ongkos total distribusi sebagai berikut.

$O T=\sum_{i=1, j=1}^{m, n} C i j . X i j$

OT

$(\mathrm{Rp} 7060 \times 7634)+(\mathrm{Rp} 12670 \times 259)+(\mathrm{Rp} 12800 \times 5223)+(\mathrm{Rp} 7130 \times 7252)+(\mathrm{Rp} 12600 \times 72)+(\mathrm{Rp} 0 \times 9$

87)

$\mathrm{OT}=\mathrm{Rp} 176.645 .930$

\section{Uji Optimasi}

Setelah dilakukan uji solusi fisibel awal menggunakan Vogel's Approximation Method (VAM) selanjutnya dilakukan uji optimalisasi untuk mendapatkan solusi yang paling optimum dengan menggunakan Modified Distribution Method (MODI). Berdasarkan hasil perhitungan 
Jurnal Lebesgue : Jurnal Ilmiah Pendidikan Matematika, Matematika dan Statistika

Reni Kurnia, Windu Alfianti Shafira, Rizka Oktaviani, Muchammad Fauzi

Volume 2, No. 2, Agustus 2021 hal.166-179

DOI Artikel : 10.46306/lb.v2i2.66

solusi fisibel awal, lakukan perhitungan nilai $\mathrm{U}$ dan $\mathrm{V}$ berdasarkan cost pada variabel basis dengan syarat jumlah variable basis harus sama dengan $\mathrm{i}+\mathrm{j}-1$ dengan $\mathrm{i}$ yaitu baris dan $\mathrm{j}$ yaitu kolom. Karena 3+7-1 = 6 sama dengan jumlah variabel basis maka perhitungan dilanjutkan yaitu evaluasi variabel basis dengan menentukan nilai $\mathrm{U}$ dan $\mathrm{V}$ pada variabel basis menggunakan asumsi salah satu nilai $u_{i}$ atau $v_{j}$ dengan bilangan bulat.

$v_{3}=$ diasumsikan bernilai 0

$c_{13}=u_{1}+v_{3} \rightarrow u_{1}=c_{13}-v_{3} \rightarrow 12670-0=12670$

$c_{12}=u_{1}+v_{2} \rightarrow v_{2}=c_{12}-u_{1} \rightarrow 7060-12670=-5610$

$c_{23}=u_{2}+v_{3} \rightarrow u_{2}=c_{23}-v_{3} \rightarrow 12800-0=12800$

$c_{33}=u_{3}+v_{3} \rightarrow u_{3}=c_{33}-v_{3} \rightarrow 12600-0=12600$

$c_{31}=u_{3}+v_{1} \rightarrow v_{1}=c_{31}-u_{3} \rightarrow 7130-12600=-5470$

$c_{43}=u_{4}+v_{3} \rightarrow u_{4}=c_{43}-v_{3} \rightarrow 0-0=0$

Selanjutnya evaluasi variable non basis dengan $x_{i j}=c_{i j}-\left(u_{i}-v_{j}\right)$

$x_{11}=c_{11}-\left(u_{1}-v_{1}\right)=7220-(12670-5470)=20$

$x_{21}=c_{21}-\left(u_{2}-v_{1}\right)=7340-(12800-5470)=10$

$x_{22}=c_{22}-\left(u_{2}-v_{2}\right)=7190-(12800-5610)=0$

$x_{32}=c_{32}-\left(u_{3}-v_{2}\right)=6980-(12600-5610)=-10$

$x_{41}=c_{41}-\left(u_{4}-v_{1}\right)=0-(0-5470)=5470$

$x_{42}=c_{42}-\left(u_{4}-v_{2}\right)=0-(0-5610)=5610$

Karena masih ada hasil evaluasi variable non basis yang bernilai negatif maka solusi belum optimal. Selanjutnya pilih variabel non basis dengan nilai negatif terbesar sebagai entering variabel $(\Theta)$. Alokasikan produk ke sel yang dipilih sesuai dengan proses stepping stone lalu lakukan iterasi ke 2 seperti pada iterasi 1 hingga nilai pada evaluasi variabel non basis nya tidak bernilai negatif.

Tabel 12. Alokasi Perbaikan Matriks MODI

\begin{tabular}{|c|c|c|c|c|c|c|}
\hline & $\begin{array}{c}\text { Tangerang } \\
\text { Selatan }\end{array}$ & \multicolumn{2}{|c|}{ Jakarta Barat } & \multicolumn{2}{|c|}{ Yogyakarta } & \multirow[t]{2}{*}{ Supply } \\
\hline & (D1) & \multicolumn{2}{|c|}{ (D2) } & \multicolumn{2}{|c|}{ (D3) } & \\
\hline \multirow{2}{*}{$\begin{array}{c}\text { Cimahi } \\
\text { (S1) }\end{array}$} & 7220 & \multirow[b]{2}{*}{7634} & 7060 & \multirow[b]{2}{*}{259} & 12670 & \multirow{2}{*}{7893} \\
\hline & & & $(-72)$ & & $(+72)$ & \\
\hline \multirow{2}{*}{$\begin{array}{c}\text { Bandung } \\
\text { (S2) }\end{array}$} & 7340 & & 7190 & \multirow{2}{*}{\multicolumn{2}{|c|}{5223}} & 527 \\
\hline & & & & & & \\
\hline
\end{tabular}


Jurnal Lebesgue : Jurnal Ilmiah Pendidikan Matematika, Matematika dan Statistika

Reni Kurnia, Windu Alfianti Shafira, Rizka Oktaviani, Muchammad Fauzi

Volume 2, No. 2, Agustus 2021 hal.166-179

DOI Artikel : 10.46306/lb.v2i2.66

\begin{tabular}{|c|c|c|c|c|c|c|c|}
\hline \multirow{2}{*}{$\begin{array}{c}\text { Padalarang } \\
\text { (S3) }\end{array}$} & \multirow[b]{2}{*}{7252} & 7130 & \multicolumn{2}{|r|}{6980} & \multicolumn{2}{|r|}{12600} & \multirow{2}{*}{7324} \\
\hline & & & $\theta$ & $(+72)$ & 72 & $(-72)$ & \\
\hline Dummy & & 0 & & 0 & \multirow{2}{*}{\multicolumn{2}{|c|}{987}} & \\
\hline & & & & & & & \\
\hline \multirow[t]{4}{*}{ Demand } & \multicolumn{2}{|c|}{7252} & \multicolumn{2}{|c|}{7634} & \multicolumn{2}{|c|}{6541} & 21427 \\
\hline & \multicolumn{6}{|c|}{ Tabel 13. Hasil Akhir Matriks MODI } & \\
\hline & \multicolumn{2}{|c|}{$\begin{array}{c}\text { Tangerang } \\
\text { Selatan }\end{array}$} & \multicolumn{2}{|c|}{ Jakarta Barat } & \multicolumn{2}{|c|}{ Yogyakarta } & Supply \\
\hline & \multicolumn{2}{|c|}{ (D1) } & \multicolumn{2}{|c|}{ (D2) } & \multicolumn{2}{|c|}{ (D3) } & \\
\hline \multirow{2}{*}{$\begin{array}{c}\text { Cimahi } \\
\text { (S1) }\end{array}$} & \multirow{2}{*}{\multicolumn{2}{|c|}{7220}} & \multirow{2}{*}{\multicolumn{2}{|c|}{7060}} & \multirow{2}{*}{\multicolumn{2}{|c|}{12670}} & \multirow{2}{*}{7893} \\
\hline & & & & & & & \\
\hline \multirow{2}{*}{$\begin{array}{c}\text { Bandung } \\
(\mathrm{S} 2)\end{array}$} & \multirow{2}{*}{\multicolumn{2}{|c|}{7340}} & & 7190 & \multirow{2}{*}{\multicolumn{2}{|c|}{5223}} & \multirow{2}{*}{5223} \\
\hline & & & & & & & \\
\hline \multirow{2}{*}{$\begin{array}{c}\text { Padalarang } \\
\text { (S3) }\end{array}$} & \multirow{2}{*}{\multicolumn{2}{|c|}{7130}} & \multirow{2}{*}{\multicolumn{2}{|c|}{6980}} & \multirow{2}{*}{\multicolumn{2}{|c|}{12600}} & \multirow{2}{*}{7324} \\
\hline & & & & & & & \\
\hline Dummy & & 0 & & 0 & \multicolumn{2}{|r|}{0} & 987 \\
\hline Demand & \multicolumn{2}{|c|}{7252} & \multicolumn{2}{|c|}{7634} & & & 21427 \\
\hline
\end{tabular}

Evaluasi variabel basis dengan menentukan nilai $u$ dan $v$ pada variabel basis menggunakan asumsi salah satu nilai $u_{i}$ atau $v_{j}$ dengan bilangan bulat

$v_{3}=$ diasumsikan bernilai 0

$$
\begin{aligned}
& c_{13}=u_{1}+v_{3} \rightarrow u_{1}=c_{13}-v_{3} \rightarrow 12670-0=12670 \\
& c_{12}=u_{1}+v_{2} \rightarrow v_{2}=c_{12}-u_{1} \rightarrow 7060-12670=-5610 \\
& c_{32}=u_{3}+v_{2} \rightarrow u_{3}=c_{33}-v_{3} \rightarrow 6980+5610=12590 \\
& c_{31}=u_{3}+v_{1} \rightarrow v_{1}=c_{31}-u_{3} \rightarrow 7130-12590=-5460 \\
& c_{23}=u_{2}+v_{3} \rightarrow u_{2}=c_{23}-v_{3} \rightarrow 12800-0=12800 \\
& c_{43}=u_{4}+v_{3} \rightarrow u_{4}=c_{43}-v_{3} \rightarrow 0-0=0
\end{aligned}
$$

Selanjutnya evaluasi variable non basis dengan $x_{i j}=c_{i j}-\left(u_{i}+v_{j}\right)$

$$
\begin{aligned}
& x_{11}=c_{11}-\left(u_{1}+v_{1}\right)=7220-(12670-5460)=10 \\
& x_{21}=c_{21}-\left(u_{2}+v_{1}\right)=7340-(12800-5460)=0 \\
& x_{22}=c_{22}-\left(u_{2}+v_{2}\right)=7190-(12800-5610)=0 \\
& x_{33}=c_{33}-\left(u_{3}+v_{3}\right)=12600-(12590-5610)=0
\end{aligned}
$$


Jurnal Lebesgue : Jurnal Ilmiah Pendidikan Matematika, Matematika dan Statistika

Reni Kurnia, Windu Alfianti Shafira, Rizka Oktaviani, Muchammad Fauzi

Volume 2, No. 2, Agustus 2021 hal.166-179

DOI Artikel : 10.46306/lb.v2i2.66

$x_{41}=c_{41}-\left(u_{4}+v_{1}\right)=0-(0-5460)=5460$

$x_{42}=c_{42}-\left(u_{4}+v_{2}\right)=0-(0-5610)=5610$

Karena sudah tidak ada hasil evaluasi variabel non basis yang hasilnya negative maka perhitungan telah optimal.

Selanjutnya dari tabel 13 dapat diperoleh ongkos total distribusi sebagai berikut.

$$
\begin{aligned}
& \text { OT }=\sum_{i=1, j=1}^{m, n} C i j . X i j \\
& \text { OT }=(\operatorname{Rp} 7060 \times 7562)+(\operatorname{Rp} 12670 \times 331)+(\operatorname{Rp} 12800 \times 5223)+(\operatorname{Rp} 7130 \times 7252)+ \\
& (\operatorname{Rp} 6980 \times 72)+(\operatorname{Rp} 0 \times 987) \\
& \text { OT }=\operatorname{Rp} 176.645 .210
\end{aligned}
$$

\section{KESIMPULAN}

Berdasarkan hasil perhitungan yang telah dilakukan menunjukkan hasil bahwa pendistribusian alat kesehatan di PT. X dengan menerapkan model transportasi dapat menghemat biaya distribusi. Solusi awal dilakukan dengan menerapkan metode VAM diperoleh biaya Rp176.645.930 kemudian dilakukan uji optimalisasi dengan menerapkan Modified Distribution Method (MODI) diperoleh biaya optimum yaitu sebesar Rp176.645.210. Biaya optimal tersebut diperoleh dari pendistribusian ke tiap kota yaitu: dari Cimahi ke Jakarta Barat 7562 produk, dari Cimahi ke Yogyakarta 331 produk, dari Bandung ke Yogyakarta 5223 produk, dari padalarang ke Tangerang Selatan 7252 produk, dan dari Padalarang ke Jakarta barat 72 produk. Pendistribusian yang dilakukan PT. X pada triwulan ketiga tahun 2020 adalah Rp.186.360.697, dan hasil perhitungan dengan metode transportasi yaitu Rp. 176.645.210. Berdasarkan hasil tersebut, PT. X dapat mengoptimalkan biaya pendistribusian sebesar Rp.9.715.697 jika menggunakan metode transportasi. Untuk mendapatkan biaya pendistribusian yang optimal, metode lain dapat digunakan untuk mencari metode yang lebih baik dalam mengoptimalkan biaya pendistribusian produk atau biaya transportasi.

\section{DAFTAR PUSTAKA}

Ardhyani, I. W. (2017). MENGOPTIMALKAN BIAYA DISTRIBUSI PAKAN TERNAK DENGAN MENGGUNAKAN METODE TRANSPORTASI (Studi Kasus di PT. X Krian). Teknika: Engineering and Sains Journal, 1(2), 95-100. https://ejournal.umaha.ac.id/index.php/teknika/article/view/128

Babu, M. A., Tabassum, J., \& Hassan, M. N. (2016). A Heuristic on Risk Management System 
in Goods Transportation Model Using Multi-Optimality by MODI Method. Open Journal of Applied Sciences, 06(08), 539-551. https://doi.org/10.4236/ojapps.2016.68054

Hussein, H. A., \& Shiker, M. A. K. (2020). A Modification to Vogel's Approximation Method to Solve Transportation Problems. https://doi.org/10.1088/1742-6596/1591/1/012029

Muhamad, G. N., Fadilah, R., \& Fauzi, M. (2020). Optimalisasi Biaya Distribusi Beras Subsidi Dengan Model Transshipment Optimizing the Cost of Distribution of Subsidized Rice Using the Transshipment Model. In Jurnal Teknik Industri (Vol. 6, Issue 1).

Mulyono, S. (2007). Riset Operasi. Lembaga Penerbit Fakultas Ekonomi Universitas Indonesia.

Nahar, J., Rusyaman, E., \& Putri, S. D. V. E. (2018). Application of improved Vogel's approximation method in minimization of rice distribution costs of Perum BULOG. IOP Conference Series: Materials Science and Engineering, 332(1), 0-8. https://doi.org/10.1088/1757-899X/332/1/012027

Pečený, L., Meško, P., Kampf, R., \& Gašparík, J. (2020). Optimisation in Transport and Logistic Processes. Transportation Research Procedia, 44(2019), 15-22. https://doi.org/10.1016/j.trpro.2020.02.003

Soplanit, P. P. G., Dundu, A. K. T., \& Mangare, J. B. (2019). METODE NWC (NORTH WEST CORNER) DAN MODI ( MODIFIED DISTRIBUTION) PADA PROYEK PEMBANGUNAN JEMBATAN DI SULAWESI UTARA. Jurnal Sipil Statik, 7(12), 1633-1640. https://ejournal.unsrat.ac.id/index.php/jss/article/view/26139

Sugiyono, P. D. (2013). Metode Penelitian Kuantitatif Kualitatif dan R\&D (19th ed.). Cv. Alfabeta.

Winda, P., \& Bb, S. (2020). Study of Unbalanced Transshipment Problems Using the Least Cost-Stepping Stone Method and the Least Cost-Modi Method Corresponding Author. In International Journal of Basic and Applied Science (Vol. 9, Issue 1). https://doi.org/10.35335/IJOBAS.V9I1.10 